Article

\title{
Integrated Underground Mining Hazard Assessment, Management, Environmental Monitoring, and Policy Control in Pakistan
}

\author{
Hammad Tariq Janjuhah ${ }^{1, *}\left(\mathbb{1}\right.$, , Muhammad Ishfaque ${ }^{2}$, Muhammad Ifzal Mehmood ${ }^{3}$, George Kontakiotis ${ }^{4}(\mathbb{D}$, \\ Syed Muzyan Shahzad ${ }^{2}\left({ }^{(1)}\right.$ and Stergios D. Zarkogiannis ${ }^{5}(\mathbb{D})$
}

Citation: Janjuhah, H.T.; Ishfaque, M.; Mehmood, M.I.; Kontakiotis, G. Shahzad, S.M.; Zarkogiannis, S.D. Integrated Underground Mining Hazard Assessment, Management, Environmental Monitoring, and Policy Control in Pakistan. Sustainability 2021, 13, 13505. https://doi.org/10.3390/ su132413505

Academic Editor: Rajesh Kumar Jyothi

Received: 2 November 2021 Accepted: 2 December 2021 Published: 7 December 2021

Publisher's Note: MDPI stays neutral with regard to jurisdictional claims in published maps and institutional affiliations.

Copyright: (c) 2021 by the authors. Licensee MDPI, Basel, Switzerland. This article is an open access article distributed under the terms and conditions of the Creative Commons Attribution (CC BY) license (https:/ / creativecommons.org/licenses/by/ $4.0 /)$.
1 Department of Geology, Shaheed Benazir Bhutto University, Sheringal, KPK, 18050, Pakistan

2 Key Laboratory of Metallogenic Prediction of Nonferrous Metal of the Ministry of Education, Central South University, Changsha 410083, China; m.ishfaque21@hotmail.com (M.I.); syed.muzayyan799@gmail.com (S.M.S.)

3 Department of Law, Shaheed Benazir Bhutto University, Sheringal, KPK, 18050, Pakistan; ifzal@sbbu.edu.pk

4 Department of Historical Geology-Paleontology, Faculty of Geology and Geoenvironment, School of Earth Sciences, National and Kapodistrian University of Athens, 15784 Athens, Greece; gkontak@geol.uoa.gr

5 Department of Earth Sciences, University of Oxford, Oxford OX1 3AN, UK; stergios.zarkogiannis@earth.ox.ac.uk

* Correspondence: hammad@sbbu.edu.pk

\begin{abstract}
This study focused on the significance of underground mining in Pakistan, resulting in the employment of operational staff to undertake the primary tasks of this sector, such as explosions, rock excavation, mineral research, mining-supporting walls, and mine compactivity. Occupational accidents and illnesses arise due to the activities mentioned above because the working circumstances are not optimal. The decision-matrix risk-assessment (DMRA) approach, in which incidents are evaluated according to their severity and probability, was also utilized to improve working conditions, including public health and environment protection. To assess the risks and to select which actions should continue in the same manner, we highlighted hazards that need control measures and, as the last option, those that must be stopped. By taking into account the results of the study, corrective actions were proposed that can help avoid the occurrence of the presented accidents through applying occupational safety and health regulations issued by the Department of Minerals and Mines, which is a governmental entity responsible for both the issuing and the compliance to those regulations. The current study also outlined the requirements that must be reported under mining-related laws.
\end{abstract}

Keywords: risk assessment; sustainable mine functioning; life cycle assessment; environment protection; environmental mining management; mine dust control; mine ventilation system; impact of contamination to human health; hazard-based safety measures; mining geology

\section{Introduction}

Construction, agriculture, and mining are the most hazardous occupational sectors in the world [1,2]. Any industry should adhere to Health, Safety, and Environment (HSE) protocols concerning accidents and occupational diseases. Among the various occupational sectors, mining is considered an important source of income globally (China, USA, Russia, Australia, India, Saudi Arabia, Indonesia, and Brazil) [1,3-5]. Mineral/metal production is essential for modern life science because it is used in a variety of products such as cars, computers, houses, roads, electrical transmission lines, jewelry, and fertilizers, among others [6,7]. Mining investments foster economic development by directly and indirectly creating jobs, social development through campaigns, and overall community improvement, thereby contributing to poverty reduction $[8,9]$. Because of the growing market demand, the mining extraction business has expanded labor without following safety standards, increasing workplace accidents [10-12]. 
Although mining is now considered a cornerstone of the Pakistan economy, because of its unique geological conditions, Pakistan is blessed with enormous mineral deposits spanning an area of $600,000 \mathrm{~km}^{2}$ [13] (Figure 1). Pakistan has a diverse range of rock types, from Pre-Cambrian to recent, with remarkable geological and geomorphological characteristics $[14,15]$. Coal, copper, gold, chromite, mineral salt, and numerous more minerals are among the 92 known minerals, 52 of which are economically utilized [16,17]. Despite its vast resources, the mining industry is performing poorly. According to the recent Economic Survey of Pakistan 2019-2020, Pakistan's mining and quarrying sector is declining by $8.82 \%$, compared to a $3.19 \%$ decline last year, and the sector contributes only $2.51 \%$ to Pakistan's Gross Domestic Product (GDP) growth. Mineral development has made a significant contribution to the economic and social development of several industrialized and emerging countries, including Russia, Australia, Canada, China, and Iran $[18,19]$.

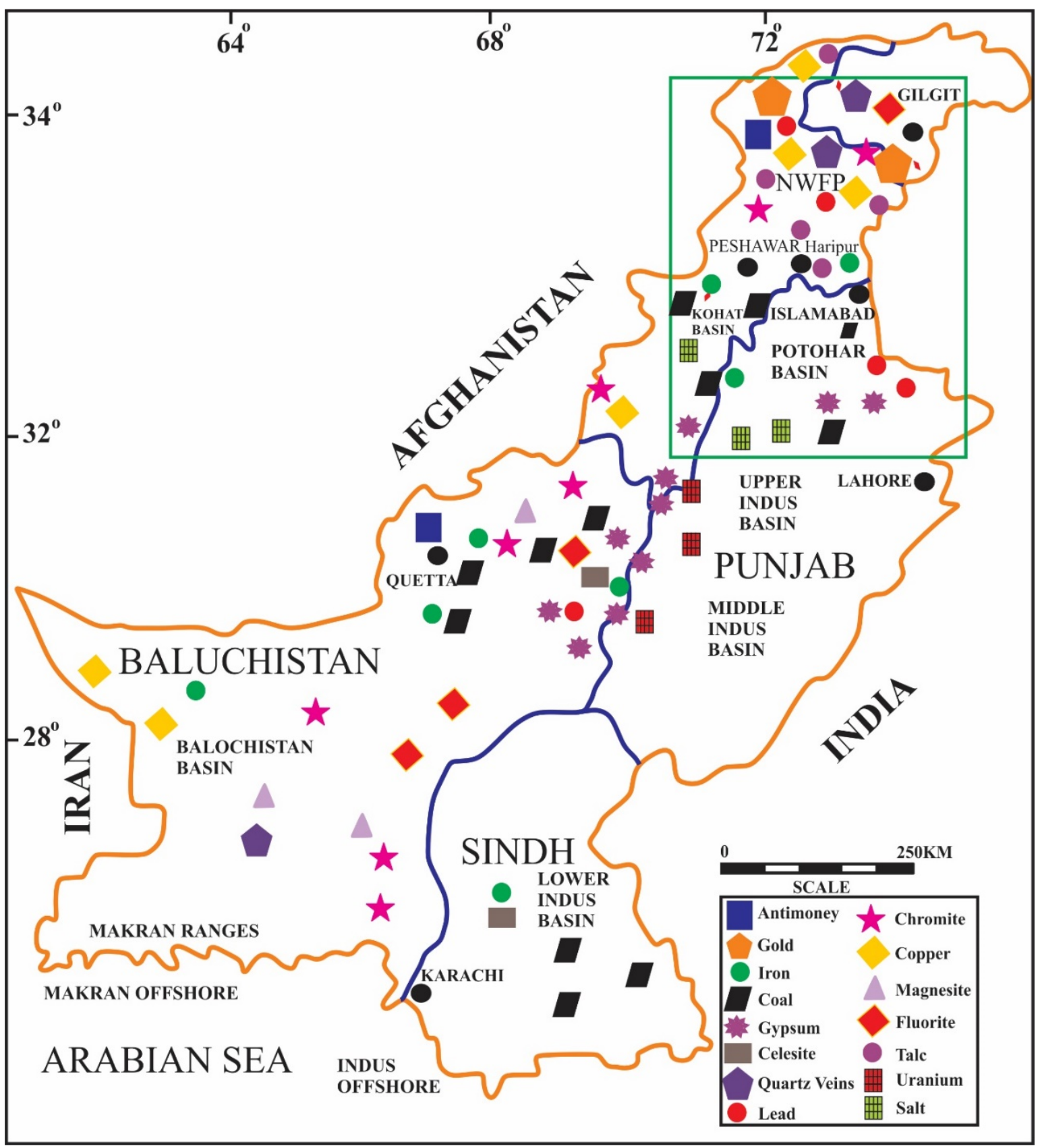

Figure 1. A synthesis map of Pakistan showing all the mineral locations. The studied mines are indicated with a green box. 
Mineral production safety is inextricably tied to a country's economic-resources sector improvement and community development [20]. Numerous fatal incidents have been documented in Pakistan due to safety management's insufficient enforcement of safety procedures (Figure 2). On 20 March 2011, 52 workers were killed after a mine collapsed in Baluchistan's Sor-Range area (Figure 2a) [21]. On 9 February 2015, a similar catastrophe occurred in the coal mines of Khyber Pakhtunkhwa province, when 19 miners were killed in a mine collapse (Figure 2b). Similarly, on 13 August 2018, a total of 18 people were killed as a result of a mine collapse in Dukki, Baluchistan (Figure 2c) [22]. On 7 September 2020, at least 22 people died, and many are still fighting for their lives in hospitals after six units of the Pakistan's legendary marble mines collapsed, resulting in large stones falls (Figure 2d). The most recent incident occurred in 12 March 2021, when six miners were killed in a blast at a coal mine in southwestern Pakistan, near the Afghan border (Figure 2e). The average incident rate of underground incidents at a national level is $11.7 \%$.
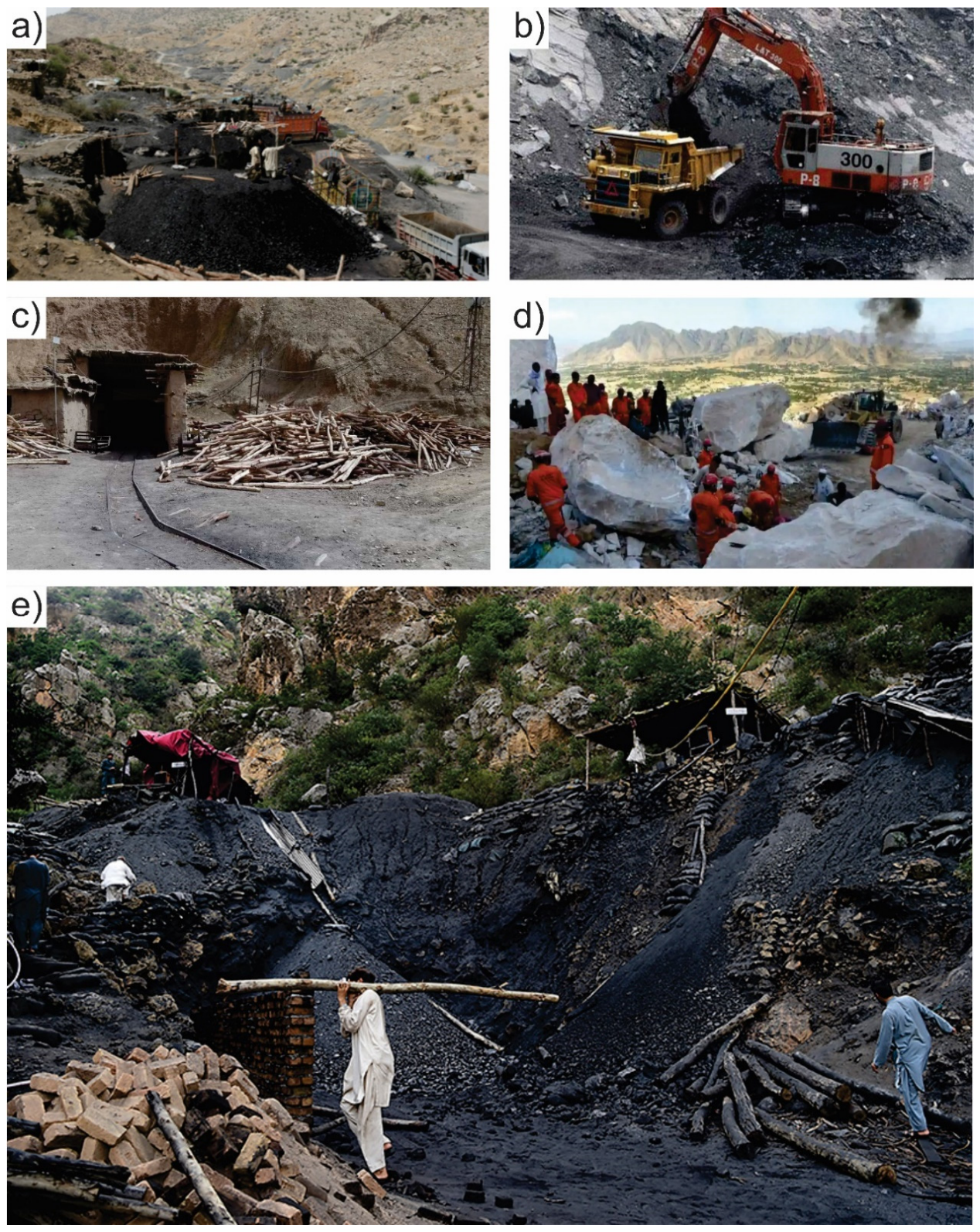

Figure 2. Mine incidents in Pakistan include (a) a 2011 mine incident in Baluchistan's SorRange region; (b) a 2015 mine incident in KPK; (c) a 2018 mine collapse in Dukki Baluchistan; (d) a 2020 marble mine collapse in Pakistan; and (e) a 2021 coal mine explosion in Southwestern Pakistan. 
The mining districts of Pakistan in four different provinces produce numerous commercial minerals, and these are the provinces with a large number of land transport routes. For the last ten years, underground mining has been one of the main economic activities of these provinces. In December 2019, Pakistan's minerals production was reported to be $49,947,390$ metric tons. It represents an increase above the previous December 2018 number of 49,104,146 metric tons. Table 1 shows the production records of four provinces (Baluchistan, Sindh, Khyber Pakhtunkhwa (KPK), and Punjab) from 2009 to 2019 based on data from Pakistan's Federal Ministry of Sustainability and Tourism.

Table 1. Production record collected from different province of Pakistan.

\begin{tabular}{|c|c|c|c|c|c|}
\hline Province & Mineral & Production (Tons) & Province & Mineral & Production (Tons) \\
\hline Baluchistan & Aragonite/marble & $1,442,346$ & Punjab & Gypsum & $1,402,367$ \\
\hline Baluchistan & Barytes & 154,637 & Punjab & Limestone & $24,390,674$ \\
\hline Baluchistan & Chromite & 55,219 & Punjab & Orchre & 68,352 \\
\hline Baluchistan & Coal & $1,671,727$ & Punjab & Rock salt & $3,465,987$ \\
\hline Baluchistan & Fluorite & 5932 & Punjab & Silica sand & 283,413 \\
\hline Baluchistan & Limestone/clay & $1,113,674$ & Punjab & Sulphur & 14,869 \\
\hline Baluchistan & Magnesite & 32,540 & $\begin{array}{c}\text { Khyber } \\
\text { Pakhtunkhwa }\end{array}$ & Antimony & 21 \\
\hline Sindh & Aragonite & 3125 & $\begin{array}{c}\text { Khyber } \\
\text { Pakhtunkhwa }\end{array}$ & $\begin{array}{l}\text { Aragonite or } \\
\text { marble }\end{array}$ & $2,473,562$ \\
\hline Sindh & China clay & 5434 & $\begin{array}{c}\text { Khyber } \\
\text { Pakhtunkhwa }\end{array}$ & Barytes & 2770 \\
\hline Sindh & Coal & 752,124 & $\begin{array}{c}\text { Khyber } \\
\text { Pakhtunkhwa }\end{array}$ & Bauxite & 3985 \\
\hline Sindh & Fuller's earth & 3049 & $\begin{array}{c}\text { Khyber } \\
\text { Pakhtunkhwa }\end{array}$ & Chromite & 4072 \\
\hline Sindh & Gravel & 420,695 & $\begin{array}{c}\text { Khyber } \\
\text { Pakhtunkhwa }\end{array}$ & Coal & 87,892 \\
\hline Sindh & Limestone & $7,361,866$ & $\begin{array}{c}\text { Khyber } \\
\text { Pakhtunkhwa }\end{array}$ & Fire clay & 10,869 \\
\hline Sindh & Silica sand & 26,972 & $\begin{array}{c}\text { Khyber } \\
\text { Pakhtunkhwa }\end{array}$ & Gypsum & 469,349 \\
\hline Punjab & Bauxite & 53,039 & $\begin{array}{c}\text { Khyber } \\
\text { Pakhtunkhwa }\end{array}$ & Limestone & $13,127,957$ \\
\hline Punjab & China clay & 16,249 & $\begin{array}{c}\text { Khyber } \\
\text { Pakhtunkhwa }\end{array}$ & Magnesite & 2688 \\
\hline Punjab & Coal & 935,019 & $\begin{array}{c}\text { Khyber } \\
\text { Pakhtunkhwa }\end{array}$ & Manganese & 70,000 \\
\hline Punjab & Fire clay & 540,108 & $\begin{array}{c}\text { Khyber } \\
\text { Pakhtunkhwa }\end{array}$ & Rock salt & 86,997 \\
\hline Punjab & Fuller's earth & 10,691 & $\begin{array}{c}\text { Khyber } \\
\text { Pakhtunkhwa }\end{array}$ & Silica sand & 85,485 \\
\hline Punjab & Gravel & 4295 & $\begin{array}{c}\text { Khyber } \\
\text { Pakhtunkhwa }\end{array}$ & Soapstone & 116,830 \\
\hline
\end{tabular}

The continued growth of investment in these provinces' mining industries results in increased production and thus the hiring of additional personnel and generates an abundance amount of dust. The dust may contain a variety of toxic metals. Dust and residues pollute the air with PHEs [23]. PHEs enter the body by dust ingestion, inhalation, skin absorption, contaminated food, and water. PHEs are toxic, durable, and bioaccumulable [24]. PHEs cause hypertension; irritability; stomach discomfort; nerve damage; skeletal issues; lung, liver, and kidney issues; intellectual deficits; fatal cardiac arrest; and cancer [25]. Underground mining is concerned with extracting minerals by excavating the land [26-28]. However, the working conditions to which workers are exposed during their shifts are suboptimal, and, as a result, work accidents and illnesses occur that affect workers' quality of life $[29,30]$. 
The risk of accidents varies according to the nature of the mine, as labor perform their tasks in confined spaces, exposing them to hazardous conditions that can result in illness or death [31,32]. According to a 2004 report on Pakistan's mineral industry by Work in Freedom, International Labor, Geneva, mechanical ventilators were installed in coal mines in Punjab beginning in 1970. Other mines, on the other hand, have continued to rely on natural ventilation methods. Despite their increasing depth, rock salt mines continue to rely on natural ventilation, although they use auxiliary and booster fans at some of the blind headings $[33,34]$. Electric safety lamps are required in mines that have been declared gassy. Non-gaseous mines, on the other hand, continue to use flame lamps for underground illumination. In Pakistan, the use of open-flame oil lamps in naturally ventilated underground mines is dangerous and detrimental to workers' health $[35,36]$. Equipment for detecting the presence of poisonous gases is uncommon in gassy mines [37]. Rather than that, caged birds are introduced into mines, and their death or fainting indicates the presence of poisonous gas [38]. When miners pass out from inhaling poisonous gas, vinegar is forced down their throats to resuscitate them. Most private coal mines continue to operate using the traditional manual haulage system [39]. Mines in the public sector, which account for less than $5 \%$ of total mines, have mechanized coal's underground and surface transportation to some extent. Even the most basic safety equipment, such as face masks or goggles, is rarely provided to workers [23,40]. The resulting statistics on workplace accidents in Pakistan's mining sector are alarming [39]. On average, more than 100 people lose their lives annually due to illness.

The overwhelming majority of miners are illiterate, under-trained, and overworked. These factors, combined with pitifully low piece-rate wages that contribute to malnutrition and poor health and necessitate long work hours, contribute to an increased risk of workplace accidents (Figure 3) [41,42]. A list of the principal hazardous conditions in the mining industry of Pakistan includes poor ventilation, low illumination and smoke inhalation, strata control, lack of mechanization, gas explosion, spontaneous combustion, ineffective supervision, sub-letting of mining leases, legislation representing occupational safety and health in mines, and the use of personal protective and safety equipment's (Figure 3) [38].

Although dispensaries were seen near mines in Choa Saiden Shah, Dandot Khushab, and Makerwal, doctors are a rarity, and there are no regular medical check-ups of the workers in any of the four provinces. According to KPK doctors' statistics, an alarming number of miners are hospitalized regularly for occupational lung diseases (e.g., pneumoconiosis) [43]. Several miner respondents confirmed the prevalence of this disease. Additionally, several workers stated that they had spent a significant amount of money on treatment for this occupational disease. The additional "shock" of medical expenses invariably results in indebtedness for individuals with already low wages.

There are additional hazards that affect mining industry laborers. Ergonomic risks relate to the tasks performed by the worker and can result in damage to sensitive parts of the musculoskeletal system, such as injuries and improper postures [44]. Psychosocial risks include anxiety and stress disorders, which contribute to an insufficient work environment, such as workplace violence $[45,46]$. Machines cause mechanical injuries, resulting in particle projection and other injuries [47,48]. Electrical installations or equipment causes electrical hazards, resulting in electric shocks if not properly maintained [49].

The analytical estimation process (AEP, qualitative-based), proportional risk-assessment (PRAT, quantitative-based), decision-matrix risk-assessment (DMRA, quantitative-based), human error analysis techniques (HEAT), event tree analysis (ETA), and risk-based maintenance (RBM) are some of the techniques used to assess risk. The quantitative-based DMRA method was utilized to obtain the risk analysis. The primary goal was to: (1) identify risk based on accident data; (2) forecast danger in hazardous conditions to prevent future fatal accidents; (3) emphasize the company's responsibility to optimize and manage risks; and (4) highlight the minerals and mining policies in Pakistan. 

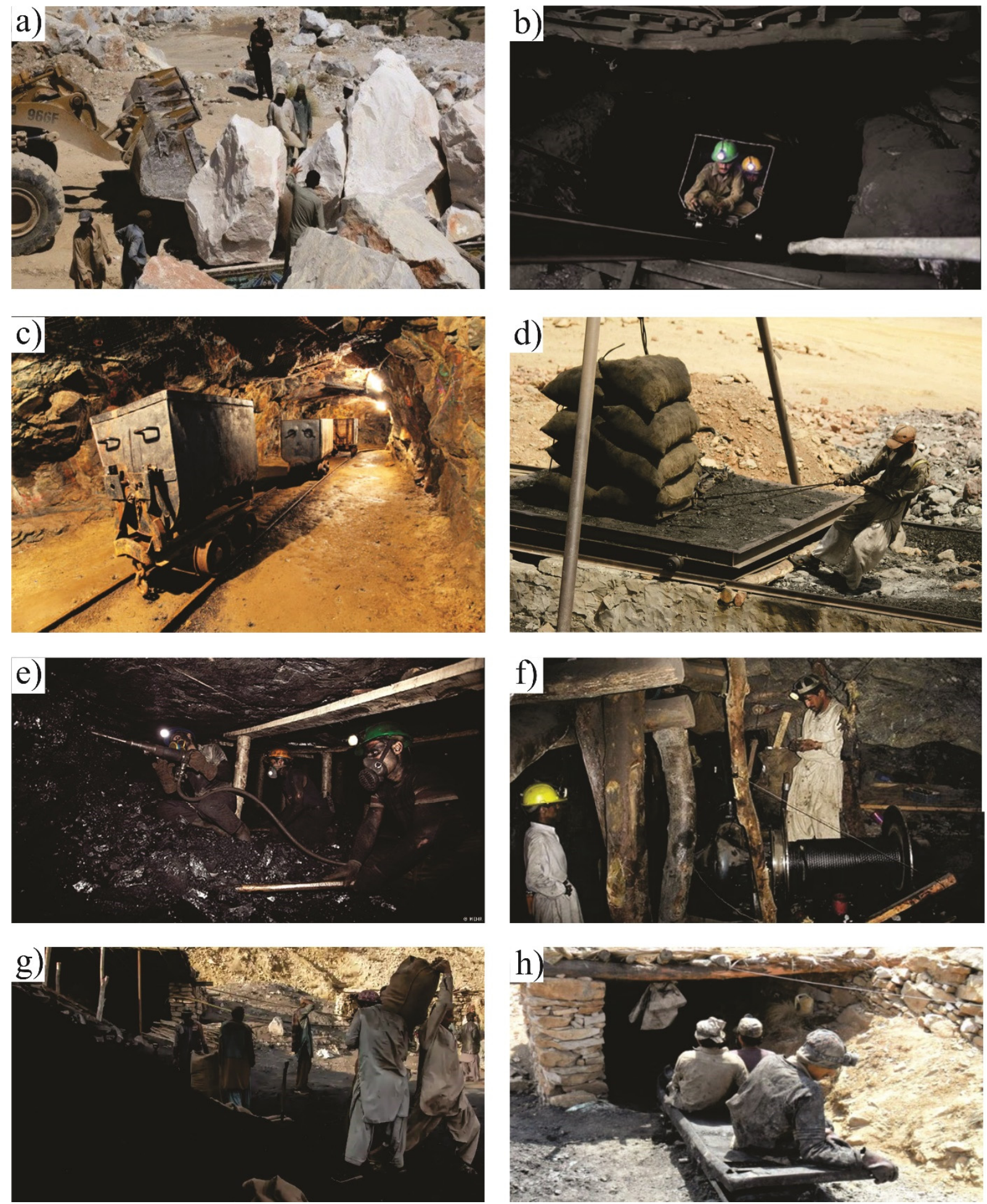

Figure 3. A list of the major hazardous conditions in Pakistan's mining industry: (a) hazards associated with the use of personal protective and safety equipment; (b) lack of mechanization; (c) ineffective supervision; (d) safety and health issues in mine; (e) low illumination and some inhalation; (f) lack of mechanization; (g) personal protective and safety equipment; (h) sub-letting of mining leases and legislation.

\section{Methodology}

The Pakistan Mineral Development Corporation is in charge of investigating complaints regarding mining incidents and safety. In this study, the risk was quantified using decision-matrix-assessment (DMA) techniques. It was accomplished through a 
questionnaire and an interview, as this is a systematic approach for estimating risk and characterizing it based on informed judgment. To cover the large territory, 28 mines are located in Punjab and KPK. The cities where mines are located are Khushab, Mansehra, Bheer-Haripur, Hasababdal, Abbottabad, Timergarah, Lower Dir, Sheringal, Dram Dala, and Lower and Upper Chitral (Figure 1).

The questionnaire and interview were performed in the first stage to cover the main information of underground mining to assess the risk, as shown in detail in Table 2. The risk value in the risk matrix is a particular value as an ultimate number of those values matching the categories of effects and probability. The probability was expressed as follows;

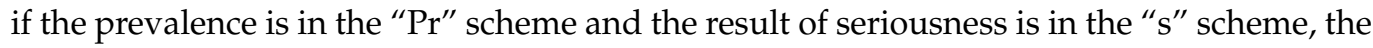
hazard factor is then labelled as "h." The probability was formalized as "minor," "major," "disastrous," "impossible," "anticipated," and "often."

Table 2. Subjective mapping of the hazards associated with carrying out underground mining operations.

\begin{tabular}{|c|c|c|c|c|c|c|c|}
\hline \multirow[t]{2}{*}{ Scheme } & \multicolumn{7}{|c|}{ Hazard } \\
\hline & Physical & Chemical & Ergonomic & Psychological & Mechanical & Electrical & Natural \\
\hline $\begin{array}{c}\text { Explosion- } \\
\text { breaks } \\
\text { mineral- } \\
\text { bearing } \\
\text { materials }\end{array}$ & $\begin{array}{c}\text { Fracture, } \\
\text { vibration, } \\
\text { noise, dust, } \\
\text { sliding, rock } \\
\text { fall, } \\
\text { temperature }\end{array}$ & $\begin{array}{l}\text { Eye infection, } \\
\text { irritation, less } \\
\text { visibility due } \\
\text { to dust and } \\
\text { explosive } \\
\text { chemical }\end{array}$ & $\begin{array}{l}\text { Vibration- } \\
\text { potential for } \\
\text { internal organ } \\
\text { damage }\end{array}$ & Anxiety & $\begin{array}{l}\text { Drill rods, drill } \\
\text { strings, and } \\
\text { rod handlers- } \\
\text { rotating and } \\
\text { moving } \\
\text { components }\end{array}$ & $\begin{array}{l}\text { Electric-wire } \\
\text { dislocation, } \\
\text { ground faults } \\
\text { or poor } \\
\text { contacts }\end{array}$ & $\begin{array}{c}\text { Land sliding, } \\
\text { land or mine } \\
\text { sinking, floods, } \\
\text { fire, } \\
\text { earthquake }\end{array}$ \\
\hline $\begin{array}{l}\text { Rock- } \\
\text { excavation } \\
\text { products and } \\
\text { equipment }\end{array}$ & $\begin{array}{l}\text { Anthropogenic } \\
\text { activity, noise, } \\
\text { artificial } \\
\text { seismicity }\end{array}$ & $\begin{array}{l}\text { Oil leakage, } \\
\text { slippery } \\
\text { surface, } \\
\text { leaching }\end{array}$ & $\begin{array}{l}\text { Equipment } \\
\text { adjustment } \\
\text { and their } \\
\text { precision }\end{array}$ & $\begin{array}{c}\text { Work } \\
\text { environment }\end{array}$ & $\begin{array}{l}\text { Moving parts, } \\
\text { friction, } \\
\text { abrasion, } \\
\text { cutting, } \\
\text { shearing, } \\
\text { puncturing, } \\
\text { crushing, } \\
\text { unnatural } \\
\text { positions }\end{array}$ & $\begin{array}{l}\text { Electrical- } \\
\text { driven } \\
\text { equipment } \\
\text { failures, } \\
\text { wireline } \\
\text { current } \\
\text { dispersion }\end{array}$ & $\begin{array}{c}\text { Fire, rock } \\
\text { sliding, slop } \\
\text { failure, } \\
\text { fractures }\end{array}$ \\
\hline $\begin{array}{c}\text { Mineral } \\
\text { exploration- } \\
\text { to determine } \\
\text { the area } \\
\text { containing } \\
\text { minerals } \\
\text { underground }\end{array}$ & $\begin{array}{c}\text { Sampling, site } \\
\text { cleanup, } \\
\text { deforestation, } \\
\text { noise, } \\
\text { vibration }\end{array}$ & $\begin{array}{c}\text { Harmful } \\
\text { chemicals, skin } \\
\text { disease, } \\
\text { corrosive } \\
\text { dermal } \\
\text { exposures }\end{array}$ & $\begin{array}{l}\text { Metabolic } \\
\text { demands of } \\
\text { repetitive tasks, } \\
\text { thermal } \\
\text { responses to } \\
\text { working in hot } \\
\text { mining }\end{array}$ & $\begin{array}{c}\text { Mental stress, } \\
\text { emotional } \\
\text { destruction, } \\
\text { conflict }\end{array}$ & $\begin{array}{l}\text { Transportation, } \\
\text { heavy } \\
\text { equipment, } \\
\text { entanglement, } \\
\text { cutting }\end{array}$ & $\begin{array}{l}\text { Power supply, } \\
\text { electrical- } \\
\text { driven } \\
\text { equipment }\end{array}$ & $\begin{array}{l}\text { Flood, mine } \\
\text { collapse, } \\
\text { fire }\end{array}$ \\
\hline $\begin{array}{l}\text { Mining- } \\
\text { supporting } \\
\text { wall-internal } \\
\text { supporting } \\
\text { structure of the } \\
\text { mine }\end{array}$ & $\begin{array}{c}\text { Infrastructure, } \\
\text { fortification, } \\
\text { ventilation, } \\
\text { access track }\end{array}$ & $\begin{array}{l}\text { Gases, harmful } \\
\text { chemicals }\end{array}$ & $\begin{array}{l}\text { Vibration- } \\
\text { potential for } \\
\text { internal organ } \\
\text { damage }\end{array}$ & $\begin{array}{l}\text { Consternation, } \\
\text { loneliness }\end{array}$ & $\begin{array}{l}\text { Join failure, } \\
\text { track damage, } \\
\text { cutting, } \\
\text { shearing, } \\
\text { ceiling bracers, } \\
\text { stamped }\end{array}$ & $\begin{array}{l}\text { Electrical- } \\
\text { driven } \\
\text { equipment } \\
\text { failures, } \\
\text { wireline } \\
\text { current } \\
\text { dispersion }\end{array}$ & $\begin{array}{l}\text { Fire, flood, } \\
\text { rock fall, } \\
\text { fracture }\end{array}$ \\
\hline $\begin{array}{l}\text { Mine } \\
\text { compactivity- } \\
\text { testing the wall } \\
\text { for labor } \\
\text { movement in } \\
\text { the mine }\end{array}$ & $\begin{array}{l}\text { Wall structure, } \\
\text { depth, area, } \\
\text { lighting }\end{array}$ & Toxicity, smoke & $\begin{array}{l}\text { Inadequate } \\
\text { and repetitive } \\
\text { postures }\end{array}$ & $\begin{array}{l}\text { Depression, } \\
\text { monotonous } \\
\text { activity }\end{array}$ & $\begin{array}{l}\text { Rock-cutting } \\
\text { equipment, } \\
\text { moving parts }\end{array}$ & $\begin{array}{l}\text { Electric-wire } \\
\text { dislocation, } \\
\text { power supply }\end{array}$ & $\begin{array}{l}\text { Fire, flood, } \\
\text { rock fall, } \\
\text { fracture }\end{array}$ \\
\hline $\begin{array}{l}\text { Road } \\
\text { accessibility- } \\
\text { transporting } \\
\text { the excavated } \\
\text { minerals }\end{array}$ & $\begin{array}{l}\text { Steep slope, } \\
\text { sliding, remote } \\
\text { area, security, } \\
\text { weather }\end{array}$ & $\begin{array}{l}\text { Lubricants, } \\
\text { toxic minerals, } \\
\text { anions }\end{array}$ & & $\begin{array}{c}\text { Road accidents, } \\
\text { wild animals' } \\
\text { interference }\end{array}$ & $\begin{array}{l}\text { Vehicles, heavy } \\
\text { machinery }\end{array}$ & Power cables & $\begin{array}{l}\text { Road damage, } \\
\text { raining, string } \\
\text { flood. }\end{array}$ \\
\hline
\end{tabular}

The continuous growth of the underground mining business has necessitated the adoption and application of new technologies and the use of novel chemicals in the processing and extraction of minerals, hence increasing the hazards associated with the 
mining sector's developing activities [7,50]. Increased activity increases employment, either directly or indirectly, and is proportional to increased risks, injuries, and even fatalities.

Excessive dust exposure is a major hazard factor for a variety of respiratory diseases. The upper respiratory tract can be irritated by short-term exposure to reparable dust. Over time, workers are at risk of developing tuberculosis, bronchitis, and occupational asthma due to long-term cumulative exposure [51]. The prevalence of occupational illnesses has increased due to a lack of progress in reducing exposure to chemical dangers in mines [52,53].

According to scholars such as Kirchsteiger [54] and $\mathrm{Ni}$ et al. [55], the categories on the hazard matrix's sides should be arranged in order of increasing danger, from minor to significant, and increasing probability, from lowest to highest (Table 3).

Table 3. Example of hazard matrix for use in hazard analysis.

\begin{tabular}{|c|c|c|c|c|c|}
\hline & & \multicolumn{4}{|c|}{ Outcome of Seriousness "s" } \\
\hline & & $\begin{array}{l}\text { Seriousness } \\
\text { Unimportant }\end{array}$ & $\begin{array}{c}\text { Seriousness } \\
\text { Important }\end{array}$ & $\begin{array}{l}\text { Serious } \\
\text { Injuries }\end{array}$ & $\begin{array}{c}\text { Major } \\
\text { Injuries }\end{array}$ \\
\hline \multirow[t]{4}{*}{ Probability } & $\begin{array}{l}\text { Prevalence } \\
\text { Pr-1 }\end{array}$ & $\mathrm{H} 1$ & $\mathrm{H} 2$ & $\mathrm{H} 4$ & H5 \\
\hline & $\begin{array}{l}\text { Prevalence } \\
\text { Pr-2 }\end{array}$ & $\mathrm{H} 2$ & H5 & H6 & H10 \\
\hline & $\begin{array}{l}\text { Prevalence } \\
\text { Pr-3 }\end{array}$ & $\mathrm{H} 3$ & $\mathrm{H} 7$ & $\mathrm{H} 8$ & H12 \\
\hline & $\begin{array}{l}\text { Prevalence } \\
\text { Pr-4 }\end{array}$ & $\mathrm{H} 4$ & H9 & H11 & H15 \\
\hline
\end{tabular}

Note: Pr-1 unpredicted, Pr-2 unpredicted, Pr-3 predicted, Pr-4, frequent, increasing danger/hazard-H1-H15, orange color-minor hazard, yellow color-moderate hazard, red color-significant hazard.

Following the accident, the damages were rated based on the harm to the environment, human life, or the company's financial standing, which means the accident's severity. The prevalence of injuries may vary by many orders of magnitude. As a result, prevalence was measured on a logarithmic scale. A severe injury's severity (outcome of seriousness) was also sometimes stated on a logarithmic scale to cover up the nature of the scale: for example, "unimportant" injury, "important" injury, "serious" injury, and "major" injury (Table 4).

Table 4. Accidents that happened between 2017 and 2019 were graded according to their severity.

\begin{tabular}{|c|c|c|c|c|}
\hline Task & $\begin{array}{l}\text { Seriousness } \\
\text { Unimportant }\end{array}$ & $\begin{array}{l}\text { Seriousness } \\
\text { Important }\end{array}$ & Serious Injuries & Major Injuries \\
\hline $\begin{array}{c}\text { Explosion-breaks } \\
\text { mineral-bearing materials }\end{array}$ & 2 & 0 & 0 & 0 \\
\hline $\begin{array}{l}\text { Rock excavation; products } \\
\text { and equipment }\end{array}$ & 5 & 3 & 2 & 0 \\
\hline $\begin{array}{l}\text { Mineral exploration-to determine the } \\
\text { area containing minerals underground }\end{array}$ & 9 & 4 & 1 & 0 \\
\hline $\begin{array}{l}\text { Mining-supporting wall-internal } \\
\text { supporting structure of the mine }\end{array}$ & 15 & 3 & 4 & 2 \\
\hline $\begin{array}{l}\text { Mine compactivity-testing the wall } \\
\text { for labor movement in the mine }\end{array}$ & 45 & 16 & 0 & 0 \\
\hline $\begin{array}{l}\text { Road accessibility-transporting the } \\
\text { excavated minerals }\end{array}$ & 4 & 1 & 0 & 0 \\
\hline
\end{tabular}

Concerning the arranged categories on the risk matrix's and the hazardous red data collected in the field, a risk matrix activity was developed according to the statistics above, considering the probability and the outcome of seriousness (risk matrix activity is marked by diagonal lines in Tables 5 and 6 ). 
Table 5. Based on the information gathered in Table 4, their hazard matrix is as follows, in accordance with the criteria outlined in Table 2 scheme 1-3.

\begin{tabular}{|c|c|c|c|c|c|}
\hline \multirow{2}{*}{\multicolumn{2}{|c|}{$\begin{array}{c}\text { Explosion-Breaks Mineral-Bearing } \\
\text { Materials }\end{array}$}} & \multicolumn{4}{|c|}{ Outcome of Seriousness "s" } \\
\hline & & $\begin{array}{l}\text { Seriousness } \\
\text { Unimportant }\end{array}$ & $\begin{array}{c}\text { Seriousness } \\
\text { Important }\end{array}$ & Serious Injuries & Major Injuries \\
\hline \multirow[t]{4}{*}{ Probability } & $\begin{array}{l}\text { Prevalence } \\
\text { Pr-1 }\end{array}$ & $\mathrm{H} 1$ & & $\mathrm{H} 4$ & H5 \\
\hline & $\begin{array}{l}\text { Prevalence } \\
\text { Pr-2 }\end{array}$ & $\mathrm{H} 2$ & H5 & H6 & H10 \\
\hline & $\begin{array}{l}\text { Prevalence } \\
\text { Pr-3 }\end{array}$ & H3 & H7 & H8 & H12 \\
\hline & $\begin{array}{l}\text { Prevalence } \\
\text { Pr-4 }\end{array}$ & $\mathrm{H} 4$ & H9 & H11 & H15 \\
\hline
\end{tabular}

\begin{tabular}{|c|c|c|c|c|c|}
\hline \multirow{2}{*}{\multicolumn{2}{|c|}{$\begin{array}{c}\text { Rock Excavation; Products and } \\
\text { Equipment }\end{array}$}} & \multicolumn{4}{|c|}{ Outcome of Seriousness "s" } \\
\hline & & $\begin{array}{l}\text { Seriousness } \\
\text { Unimportant }\end{array}$ & $\begin{array}{c}\text { Seriousness } \\
\text { Important }\end{array}$ & Serious Injuries & Major Injuries \\
\hline \multirow[t]{4}{*}{ Probability } & $\begin{array}{l}\text { Prevalence } \\
\text { Pr-1 }\end{array}$ & $\mathrm{H} 1$ & $\mathrm{H} 2$ & $\mathrm{H} 4$ & $\mathrm{H} 5$ \\
\hline & $\begin{array}{c}\text { Prevalence } \\
\text { Pr-2 }\end{array}$ & $\mathrm{H} 2$ & & H6 & $\mathrm{H} 10$ \\
\hline & $\begin{array}{c}\text { Prevalence } \\
\text { Pr-3 }\end{array}$ & $\mathrm{H} 3$ & H7 & H8 & H12 \\
\hline & $\begin{array}{c}\text { Prevalence } \\
\text { Pr-4 }\end{array}$ & $\mathrm{H} 4$ & H9 & H11 & H15 \\
\hline \multirow{2}{*}{\multicolumn{2}{|c|}{$\begin{array}{c}\text { Mineral Exploration-to Determine } \\
\text { the Area Containing Minerals } \\
\text { Underground }\end{array}$}} & \multicolumn{4}{|c|}{ Outcome of Seriousness "s" } \\
\hline & & $\begin{array}{l}\text { Seriousness } \\
\text { Unimportant }\end{array}$ & $\begin{array}{l}\text { Seriousness } \\
\text { Important }\end{array}$ & Serious Injuries & Major Injuries \\
\hline \multirow[t]{4}{*}{ Probability } & $\begin{array}{l}\text { Prevalence } \\
\text { Pr-1 }\end{array}$ & $\mathrm{H} 1$ & $\mathrm{H} 2$ & $\mathrm{H} 4$ & H5 \\
\hline & $\begin{array}{c}\text { Prevalence } \\
\text { Pr-2 }\end{array}$ & $\mathrm{H} 2$ & & H6 & H10 \\
\hline & $\begin{array}{c}\text { Prevalence } \\
\text { Pr-3 }\end{array}$ & H3 & $\mathrm{H} 7$ & H8 & H12 \\
\hline & $\begin{array}{c}\text { Prevalence } \\
\text { Pr- } 4\end{array}$ & $\mathrm{H} 4$ & H9 & H11 & H15 \\
\hline
\end{tabular}

Note: Pr-1 unpredicted, Pr-2 unpredicted, Pr-3 predicted, Pr-4, frequent, increasing danger/hazard-H1-H15, orange color-minor hazard, yellow color-moderate hazard, red color-significant hazard.

Table 6. According to the criteria given in Table 2 schemes 4-6, their hazard matrix is based on the data collected in Table 4.

\begin{tabular}{|c|c|c|c|c|}
\hline \multirow{2}{*}{$\begin{array}{l}\text { Mining-Supporting Wall-Internal } \\
\text { Supporting Structure of the Mine }\end{array}$} & \multicolumn{4}{|c|}{ Outcome of Seriousness "s" } \\
\hline & $\begin{array}{l}\text { Seriousness } \\
\text { Unimportant }\end{array}$ & $\begin{array}{l}\text { Seriousness } \\
\text { Important }\end{array}$ & Serious Injuries & Major Injuries \\
\hline $\begin{array}{c}\text { Prevalence } \\
\text { Pr-1 }\end{array}$ & $\mathrm{H} 1$ & $\mathrm{H} 2$ & $\mathrm{H} 4$ & H5 \\
\hline $\begin{array}{l}\text { Prevalence } \\
\text { Pr-2 }\end{array}$ & $\mathrm{H} 2$ & H5 & H6 & H10 \\
\hline $\begin{array}{l}\text { Prevalence } \\
\text { Pr-3 }\end{array}$ & H3 & H7 & $\mathrm{H} 8$ & H12 \\
\hline $\begin{array}{l}\text { Prevalence } \\
\text { Pr-4 }\end{array}$ & $\mathrm{H} 4$ & H9 & H11 & H15 \\
\hline
\end{tabular}


Table 6. Cont.

\begin{tabular}{|c|c|c|c|c|}
\hline \multirow{2}{*}{$\begin{array}{l}\text { Mine Compactivity-Testing the } \\
\text { Wall for Labor Movement in the } \\
\text { Mine }\end{array}$} & \multicolumn{4}{|c|}{ Outcome of Seriousness "s" } \\
\hline & $\begin{array}{l}\text { Seriousness } \\
\text { Unimportant }\end{array}$ & $\begin{array}{l}\text { Seriousness } \\
\text { Important }\end{array}$ & Serious Injuries & Major Injuries \\
\hline $\begin{array}{c}\text { Prevalence } \\
\text { Pr-1 }\end{array}$ & $\mathrm{H} 1$ & $\mathrm{H} 2$ & $\mathrm{H} 4$ & H5 \\
\hline $\begin{array}{l}\text { Prevalence } \\
\text { Pr-2 }\end{array}$ & $\mathrm{H} 2$ & H5 & H6 & $\mathrm{H} 10$ \\
\hline $\begin{array}{l}\text { Prevalence } \\
\text { Pr-3 }\end{array}$ & $\mathrm{H} 3$ & & H8 & H12 \\
\hline $\begin{array}{c}\text { Prevalence } \\
\text { Pr-4 }\end{array}$ & $\mathrm{H} 4$ & $\mathrm{H} 9$ & H11 & H15 \\
\hline \multirow{2}{*}{$\begin{array}{c}\text { Road Accessibility-Transporting } \\
\text { the Excavated Minerals }\end{array}$} & \multicolumn{4}{|c|}{ Outcome of Seriousness "s" } \\
\hline & $\begin{array}{l}\text { Seriousness } \\
\text { Unimportant }\end{array}$ & $\begin{array}{l}\text { Seriousness } \\
\text { Important }\end{array}$ & Serious Injuries & Major Injuries \\
\hline $\begin{array}{c}\text { Prevalence } \\
\text { Pr-1 }\end{array}$ & $\mathrm{H} 1$ & $\mathrm{H} 2$ & $\mathrm{H} 4$ & H5 \\
\hline $\begin{array}{l}\text { Prevalence } \\
\text { Pr-2 }\end{array}$ & $\mathrm{H} 2$ & & H6 & H10 \\
\hline $\begin{array}{c}\text { Prevalence } \\
\text { Pr-3 }\end{array}$ & $\mathrm{H} 3$ & H7 & H8 & H12 \\
\hline $\begin{array}{c}\text { Prevalence } \\
\text { Pr-4 }\end{array}$ & $\mathrm{H} 4$ & H9 & H11 & H15 \\
\hline
\end{tabular}

Note: Pr-1 unpredicted, Pr-2 unpredicted, Pr-3 predicted, Pr-4, frequent, increasing danger/hazard-H1-H15, orange color-minor hazard, yellow color-moderate hazard, red color-significant hazard.

\section{Results and Discussion}

Gul and Guneri [56] used decision-matrix risk assessment to rank the risks such that they were better suited to real-world situations rather than random numbers. A hazardcontrol hierarchy is needed to lower the hazards [57,58]. Control methods to mitigate hazards in the field may be determined using the order of hierarchy of control as in Zhou and Yang [59]. This sequence is the most effective technique for dealing with the hazard. If the optimal control method is not possible, the following steps may be used to reduce the hazard. Regardless of whether or not the decision-matrix risk-assessment (DMRA) method is used and based on the assessment of explosion-related activities, the mineral-bearing minerals are broken, and rock excavation products and equipment are destroyed [60]. In mineral exploration, the goal is to find out where the mineral deposits are located underground [61,62]. In mining, the goal is to test the wall for labor movement in the mine, and, in road accessibility, the goal is to transport the excavated minerals to the proper location within the matrix without causing any major harm or recoverable injuries $[63,64]$. Aside from a few serious casualties, many miners were wounded due to the industry's preventative measures $[65,66]$. However, it is essential to remember that a member of the security crew was seriously injured during the rock excavation.

A hazard magnitude analysis was carried out using the MMG-15-Nov-2017 (Mineral and Mines Act, KPK, Pakistan), in which the actions are specified depending on the level of hazard associated with each work task. According to the data in Table 5 scheme 1, there have only been a few minor explosions, which implies no one has been harmed, and just one person has died due to them. The MMG-15-Nov-2017 (Mineral and Mines Act, KPK, Pakistan), on the other hand, is used to categories the intensity of the risk into four categories: high, medium, low, and minimal. As a result, in an explosion, the following actions should be taken: minimal hazard requires immediate attention; low hazard requires immediate attention and correction if necessary; and high hazard requires that immediate attention and security conditions are revised as soon as possible if they are not already. The risk is reduced to a bare minimum (Table 7). Onifade [67] and Gomes and Silva [24] suggested the following control actions for risks that are at the top of the explosion rankings 
(e.g., excessive exposure to heat, inhalation of blasting powder and smoke, and skin burns from a hot material are all serious risks in the mining industries).

Table 7. The probability and outcomes of the severity of the explosive activity.

\begin{tabular}{ccccc}
\hline $\begin{array}{c}\text { Explosion-Breaks } \\
\text { Mineral-Bearing } \\
\text { Materials }\end{array}$ & \multicolumn{2}{c}{ Outcome of Seriousness "s" } \\
\cline { 2 - 5 } & $\begin{array}{c}\text { Seriousness } \\
\text { Unimportant }\end{array}$ & $\begin{array}{c}\text { Seriousness } \\
\text { Important }\end{array}$ & Serious Injuries & Major Injuries \\
\hline Accidents & 2 & 0 & 0 & 0 \\
\hline Probability of its & Prevalence & Prevalence & Prevalence & Prevalence \\
consequences & Pr-1 & Pr-3 & H2 & H5 \\
\hline Hazard factor & $\mathrm{H} 1$ & Slightly injuries and major injuries \\
\hline
\end{tabular}

Note: Pr-1 unpredicted, Pr-2 unpredicted, Pr-3 predicted, Pr-4, frequent, increasing danger/hazard-H1-H15, orange color-minor hazard, yellow color-moderate hazard.

Currently, the only control mechanisms for these kinds of hazards require workers to operate in safe conditions with appropriate tools and equipment $[68,69]$. The vacuum system in the mining room has to be strengthened as an additional control measure [70-72].

According to the data, about five incidents involving two severely wounded people have been linked to gravel mining, putting it exactly at the intersection of prevalence Pr-2: the severity of serious injuries related to a hazard factor H4 (Table 8). It has been established that they cannot provide any personal damage or significant injuries, even if one of them is to a woman's fertility. A new death that happens unexpectedly and without warning should be prevented at all costs by adopting extra precautions. Hazardous mineral exploration and rock extraction should be subjected to several controls $[7,73]$. However, the MMG-15-Nov-2017 method is utilized for more precise outcome analysis. The following steps should be done based on the hazard of rock excavation products and equipment: low risk requires attention and, if necessary, correction; moderate and high risk requires immediate action. This activity has resulted in one fatality, and significant injuries with a high hazard factor need immediate medical attention (Table 8). According to Sanjana and Prathilothamai [74], Suryoputro et al. [75], and Ilo et al. [76], in the event of an emergency, a sprinkler and alarm system should be installed.

Table 8. The probability and outcomes of the severity of rock excavation.

\begin{tabular}{|c|c|c|c|c|}
\hline \multirow{2}{*}{$\begin{array}{c}\text { Rock Excavation; } \\
\text { Products and Equipment }\end{array}$} & \multicolumn{4}{|c|}{ Outcome of Seriousness "s" } \\
\hline & $\begin{array}{l}\text { Seriousness } \\
\text { Unimportant }\end{array}$ & $\begin{array}{l}\text { Seriousness } \\
\text { Important }\end{array}$ & Serious Injuries & Major Injuries \\
\hline Accidents & 5 & 3 & 2 & 0 \\
\hline $\begin{array}{l}\text { Probability of its } \\
\text { consequences }\end{array}$ & $\begin{array}{l}\text { Prevalence } \\
\text { Pr-1 }\end{array}$ & $\begin{array}{l}\text { Prevalence } \\
\text { Pr-2 }\end{array}$ & $\begin{array}{l}\text { Prevalence } \\
\text { Pr-3 }\end{array}$ & $\begin{array}{l}\text { Prevalence } \\
\text { Pr-4 }\end{array}$ \\
\hline \multirow[t]{2}{*}{ Hazard factor } & $\mathrm{H} 2$ & H5 & $\mathrm{H} 4$ & H5 \\
\hline & No human harm & & njuries and major $\mathrm{i}$ & \\
\hline
\end{tabular}

Note: Pr-1 unpredicted, Pr-2 unpredicted, Pr-3 predicted, Pr-4, frequent, increasing danger/hazard-H1-H15, orange color—minor hazard, yellow color-moderate hazard.

There have been 14 mineral-exploration incidents classified as minor or severe in severity. It has been proven that they can be given no personal damage but only one serious injury and no major injuries (Table 9). A further in-depth examination of the results (MMG15-Nov-2017) shows that the risk of severe injuries is not that great (Table 9). Excessive noise is generated throughout the exploration and mineral-exploration processes [77,78]. To combat this, wear a pair of quality earplugs [79]. Employees who use earplugs regularly should monitor their usage [80]. Falling heavy equipment during replacement is the most significant danger [81]. As a consequence, stacking rules should be followed as a preventative measure. 
Table 9. The probability and results of the severity of mineral exploration.

\begin{tabular}{ccccc}
\hline $\begin{array}{c}\text { Mineral Exploration-to Determine } \\
\text { the Area Containing Minerals } \\
\text { Underground }\end{array}$ & \multicolumn{4}{c}{ Outcome of Seriousness "s" } \\
\cline { 2 - 5 } & $\begin{array}{c}\text { Seriousness } \\
\text { Unimportant }\end{array}$ & $\begin{array}{c}\text { Seriousness } \\
\text { Important }\end{array}$ & Serious Injuries & Major Injuries \\
\hline Accidents & 9 & 4 & 1 & 0 \\
\hline Probability of its consequences & $\begin{array}{c}\text { Prevalence } \\
\text { Pr-1 }\end{array}$ & $\begin{array}{c}\text { Prevalence } \\
\text { Pr-2 }\end{array}$ & $\begin{array}{c}\text { Prevalence } \\
\text { Pr-3 }\end{array}$ & Prevalence \\
Pr-4 & H6 & H5 \\
\hline Hazard factor & H3 & H5 & Serious injuries and major injuries \\
\hline
\end{tabular}

Note: Pr-1 unpredicted, Pr-2 unpredicted, Pr-3 predicted, Pr-4, frequent, increasing danger/hazard-H1-H15, orange color-minor hazard, yellow color-moderate hazard.

The unimportant seriousness and important seriousness of 24 mining-supporting-wall accidents were classified. Moderate risks require attention and adjustments if necessary for mining-supporting-wall/internal supporting structures, while high-risk activities necessitate urgent attention and a review of security conditions (Table 10). When it comes to mine-supporting walls and compactivity testing, there is available protective equipment for the danger (such as equipment for assessing worker movement inside mine walls) [82,83]. Even so, if the protective gear is required to be permanently placed, a warning signal system must be put in place [84].

Table 10. The probability and results of the mining-supporting walls' seriousness.

\begin{tabular}{ccccc}
\hline $\begin{array}{c}\text { Mining-Supporting } \\
\text { Wall-Internal Supporting } \\
\text { Structure of the Mine }\end{array}$ & $\begin{array}{c}\text { Seriousness } \\
\text { Unimportant }\end{array}$ & $\begin{array}{c}\text { Seriousness } \\
\text { Important }\end{array}$ & Serious Injuries & Major Injuries \\
\cline { 2 - 5 } Accidents & 15 & 3 & 4 & 2 \\
\hline Probability of its consequences & Prevalence & Prevalence & Prevalence & Prevalence \\
& Pr-1 & Pr-2 & Pr-3 & H8 \\
\hline Hazard factor & & H7 & H10 & \\
\hline
\end{tabular}

Note: Pr-1 unpredicted, Pr-2 unpredicted, Pr-3 predicted, Pr-4, frequent, increasing danger/hazard-H1-H15, yellow color-moderate hazard, red color-significant hazard.

There were 61 accidents involving mine compactivity activities, with the severity ranging from minor to major (Table 11). It has been decided that no one will be harmed or killed, and there will be no injuries. According to the results of the MMG-15-Nov2017 study, the following actions should be done to improve mine compactivity: pay attention to low risks, pay attention to high hazards, and make corrections where necessary (Table 11). Around 61 accidents occurred during road-accessibility activities that were categorized as minor or major. The road-accessibility activity shows a moderate degree of danger based on the MMG-15-Nov-2017, which shows that the risk of severe injuries is not great (Table 12).

Table 11. The probability and results of the mine compactivity's severity.

\begin{tabular}{ccccc}
\hline $\begin{array}{l}\text { Mine Compactivity-Testing the } \\
\text { Wall for Labor Movement in the } \\
\text { Mine }\end{array}$ & \multicolumn{4}{c}{ Outcome of Seriousness "s" } \\
\cline { 2 - 5 } & $\begin{array}{c}\text { Seriousness } \\
\text { Unimportant }\end{array}$ & $\begin{array}{c}\text { Seriousness } \\
\text { Important }\end{array}$ & Serious Injuries & Major Injuries \\
\hline Accidents & 45 & 16 & 0 & 0 \\
\hline \multirow{2}{*}{$\begin{array}{c}\text { Probability of its consequences } \\
\text { Hazard factor }\end{array}$} & $\begin{array}{c}\text { Prevalence } \\
\text { Pr-1 }\end{array}$ & $\begin{array}{c}\text { Prevalence } \\
\text { Pr-2 }\end{array}$ & $\begin{array}{c}\text { Prevalence } \\
\text { Pr-3 }\end{array}$ & Prevalence \\
Pr-4 & H4 & H5 \\
\hline
\end{tabular}

Note: Pr-1 unpredicted, Pr-2 unpredicted, Pr-3 predicted, Pr-4, frequent, increasing danger/hazard-H1-H15, yellow color-moderate hazard. 
Table 12. The probability and outcomes of the severity of road accessibility.

\begin{tabular}{|c|c|c|c|c|}
\hline \multirow{2}{*}{$\begin{array}{l}\text { Road } \\
\text { Accessibility-Transport the } \\
\text { Excavated Minerals }\end{array}$} & \multicolumn{4}{|c|}{ Outcome of Seriousness "s" } \\
\hline & $\begin{array}{l}\text { Seriousness } \\
\text { Unimportant }\end{array}$ & $\begin{array}{l}\text { Seriousness } \\
\text { Important }\end{array}$ & Serious Injuries & Major Injuries \\
\hline Accidents & 45 & 16 & 0 & 0 \\
\hline Probability of its consequences & $\begin{array}{l}\text { Prevalence } \\
\text { Pr-1 }\end{array}$ & $\begin{array}{c}\text { Prevalence } \\
\text { Pr-2 }\end{array}$ & $\begin{array}{l}\text { Prevalence } \\
\text { Pr-3 }\end{array}$ & $\begin{array}{l}\text { Prevalence } \\
\text { Pr-4 }\end{array}$ \\
\hline Hazard factor & $\mathrm{H} 4$ & H7 & $\mathrm{H} 4$ & H5 \\
\hline
\end{tabular}

Note: Pr-1 unpredicted, Pr-2 unpredicted, Pr-3 predicted, Pr-4, frequent, increasing danger/hazard-H1-H15, yellow color-moderate hazard.

The mine's safety equipment should be examined on a regular basis to ensure that the oxygen level is kept under control $[85,86]$. Employees' usage of earplugs should be monitored to ensure success. Additionally, there is a risk while using hand-drilling equipment [87]. Installing emergency stop wires throughout the mine's line environment will be more effective in preventing hand finger jamming and wounding in the operating region. The following control measures should be implemented to minimize the hazards associated with explosions, rock excavation, mineral exploration, mining-supporting walls, and mine compactivity. While working, the operator must wear safety eyewear at all times. During mine labor, the miner must wear a hard protective safety helmet. The manufacturing hall's operating area needs more coupling guards to avoid injuries and limb loss [88]. The risk assessment process should be seen as an ongoing one, and the effectiveness of control measures should be reviewed and revised as needed $[69,89]$.

\section{Law Policies of Mineral and Mines in Pakistan}

A mining policy should be developed to avoid incidents and to improve labor standards in the country. Certain measurements have been presented for incident reduction safety in mining operations.

1. It should be noted that "uneducated" and "unskilled" are not comparable, and the idea that education determines skill level is incredible.

2. Off-nominal conduct may be a safety violation if the person doing it has not received proper training.

3. Due to the severe nature of mining hazards, it is hard to believe miners would purposefully endanger their own and their colleagues' lives if properly educated and trained.

4. If miners lack the skills required to operate safely in a mine, inadequate training is the major cause. Mine owners, managers, and regulators are responsible for miner safety training.

Explosives in mining operations have resulted in several accidents, including fatalities, structural damage, mine slides, and uncontrolled subsurface reservoir blasting. The Pakistan government designed the Khyber-Pakhtunkhwa Act of 2013 to ensure appropriate explosive storage and management in mining. The appropriate department develops the controlled blast strategy. Although policies exist, they are not implemented, which leads to the incidence. Secondly, the Licensing Authority investigates mineral property damage caused by leaseholders. The leaseholders may be responsible for such damages if the Licensing Authority grants the holder a fair hearing. According to articles 47 and 47-A, the use of explosives in mining must be reported to the Department of Mines and Minerals. To produce any minerals, the mineral owner must use scientific techniques. Sub-article 6 of the Mineral Act 2017 states that holders of prospecting licenses must safely seal all holes and cover-up or fence any holes or excavations in the mining region. The ground surface and any structures harmed by mining must be repaired. Encroachment on a mineral lease territory is punished by up to five years of imprisonment and a fine of two million rupees. The leaseholder should submit monthly production reports and mineral dispatch to the Licensing Authority appropriately (Article 43-1). Monthly output returns 
must be accompanied by a challan showing royalty and other dues paid. Article 47-A sub-section-2 requires every leaseholder to install apparatus and equipment for mining scientific research.

\section{Recommendations}

The geological condition influences the panel arrangement, the mining process, and wall and roof management. Simple geological formations and excellent surrounding rock qualities are general geological traits. It is important to note that overburden characteristics, the mining depth $(\mathrm{m})$, the angle of the mine, and the reservoir trend are essential parameters for mining-structure stability (damage of overburden strata, surface movement, and deformation). Subsurface-mining support systems provide mine stability, such as in Wongawilli strip and pillar mining. Strip mining reduces overloaded strata, surface movement, and deformation. Strip mining causes less surface subsidence than underground long wall mining. Some flaws include poor mining efficiency and excessive driving rater. Both the strip pillar and Wongawilli mining processes may benefit from technology. It tries to resolve issues with coal mining beneath buildings, railways, and water bodies. The US, Canada, Australia, India, and South Africa employ room and pillar mining. It is also used in Dongsheng, Da Liuzhuang, in Shanxi, Nantun, in Huangling, and in Yanzhou.

Mine stability is critical for effective operational management and safety criteria. Although specific ancient techniques are still used to evaluate mine strength and stability, technological advances have reduced costs and time. Mine Mobile Inspection Robots (GMRI) and Ground-Penetrating Radar (GPR) are the newest tools for predicting geological and structural stability in a growing nation. These technologies forecast the danger zone during mining operations, which is helpful for worker safety. The developing country's government should adopt a mining strategy for standardized scientific mining to avoid future disasters.

\section{Conclusions}

The risk-assessment matrix allows organizations to categorize work incidents as orange (no injuries), yellow (recoverable injuries, one fatality, and many injuries), or red (multiple injuries, several deaths, and many injured). Risk assessors may use colors to alert them to workplace issues. In addition to the previous research, the following are methods to prevent workplace accidents and illnesses. Based on the resulting conclusion, we understand that, for explosions, ensuring workers are trained in the use and handling of explosives and providing protective gear are some of the most important preventative measures. Using and managing machinery and equipment poses physical, chemical, ergonomic, mechanical, electrical, and natural hazards. Emergency stops, machine and equipment operating training, an internal control license, and necessary PPE should be available. Work processes must contain hazard-based safety measures and constraints. personal protective equipment (PPE), repetitive postures and activities (RPA), hazardous chemical substances (HCS), and safe operation of machinery and equipment are among the topics covered in workplace safety training (M\&E). Finally, staff should be educated on the importance of safe work practices. Safety training, secure work methods, material handling and storage, and manual load safety measures should be included in exploration and exploitation.

Author Contributions: Conceptualization, H.T.J.; methodology, H.T.J. and S.M.S.; software, H.T.J. and M.I.; validation, H.T.J.; formal analysis, H.T.J.; investigation, H.T.J.; resources, H.T.J.; data curation, H.T.J.; writing—original draft preparation, H.T.J.; writing—review and editing, H.T.J., G.K., S.D.Z. and M.I.M.; visualization, H.T.J.; supervision, H.T.J.; project administration, H.T.J.; funding acquisition, G.K. All authors have read and agreed to the published version of the manuscript.

Funding: This research received no external funding.

Institutional Review Board Statement: Not applicable.

Informed Consent Statement: Not applicable. 


\section{Data Availability Statement: Not applicable.}

Acknowledgments: The corresponding author would like to thank Badsha Hussain, Registrar, SBBU, Alam Zaib, Director QEC, SBBU, Badshah Said, Deputy Director Teaching and Admissions, SBBU, faculty members of the geology department, and all of SBBU's academic and administrative personnel for their support during this work.

Conflicts of Interest: The authors declare no conflict of interest.

\section{References}

1. Domínguez, C.R.; Martínez, I.V.; Peña, P.M.P.; Ochoa, A.R. Analysis and evaluation of risks in underground mining using the decision matrix risk-assessment (DMRA) technique, in Guanajuato, Mexico. J. Sustain. Min. 2019, 18, 52-59. [CrossRef]

2. Hentschel, T.; Hruschka, F.; Priester, M. Global Report on Artisanal and Small-Scale Mining, Report Commissioned by the Mining, Minerals and Sustainable Development of the International Institute for Environment and Development. 2002, Volume 20, p. 2008. Available online: http://www.iied.org/mmsd/mmsd_pdfs/asm_global_report_draft_jan02 (accessed on 1 October 2021).

3. Azapagic, A. Developing a framework for sustainable development indicators for the mining and minerals industry. J. Clean. Prod. 2004, 12, 639-662. [CrossRef]

4. Benites, A.J.; Simões, A.F. Assessing the urban sustainable development strategy: An application of a smart city services sustainability taxonomy. Ecol. Indic. 2021, 127, 107734. [CrossRef]

5. Duro, A.; Piccione, V.; Ragusa, M.; Veneziano, V. New enviromentally sensitive patch index-ESPI-for MEDALUS protocol. In Proceedings of the 10th International Conference on Mathematical Problems in Engineering, Aerospace and Sciences: ICNPAA 2014, Narvik, Norway, 15-18 July 2014; pp. 305-312.

6. Almeida, C.; Ruas, F.; Godinho, M.; Martins, A. Teaching Science Problem Based Learning (PBL) Implementation of Rocks and Minerals. In EGU General Assembly Conference Abstracts; 2016; p. EPSC2016-8644. Available online: https://ui.adsabs.harvard. edu/abs/2016EGUGA..18.8644A/abstract (accessed on 1 October 2021).

7. Rebello, S.; Anoopkumar, A.; Aneesh, E.M.; Sindhu, R.; Binod, P.; Kim, S.H.; Pandey, A. Hazardous minerals mining: Challenges and solutions. J. Hazard. Mater. 2021, 402, 123474. [CrossRef] [PubMed]

8. Yadoo, A.; Cruickshank, H. The role for low carbon electrification technologies in poverty reduction and climate change strategies: A focus on renewable energy mini-grids with case studies in Nepal, Peru and Kenya. Energy Policy 2012, 42, 591-602. [CrossRef]

9. Foo, N.; Bloch, H.; Salim, R. The optimisation rule for investment in mining projects. Resour. Policy 2018, 55, 123-132. [CrossRef]

10. Council, N.R. Mining Safety and Health Research at NIOSH: Reviews of Research Programs of the National Institute for Occupational Safety and Health; National Academies Press: Washington, DC, USA, 2007; Volume 2.

11. Laurence, D. Establishing a sustainable mining operation: An overview. J. Clean. Prod. 2011, 19, 278-284. [CrossRef]

12. Pietilä, J.; Räsänen, T.; Reiman, A.; Ratilainen, H.; Helander, E. Characteristics and determinants of recurrent occupational accidents. Saf. Sci. 2018, 108, 269-277. [CrossRef]

13. Malkani, M.S.; Mahmood, Z. Mineral resources of Pakistan: A review. Geol. Surv. Pak. Rec. 2016, 128, 1-90.

14. Ullah, M.F.; Mahmood, K.; Akram, M.S. Coal mining trends and future prospects: A case study of Eastern Salt Range, Punjab, Pakistan. J. Himal. Earth Sci. 2018, 51, 87-93.

15. Khan, U.; Janjuhah, H.T.; Kontakiotis, G.; Rehman, A.; Zarkogiannis, S.D. Natural Processes and Anthropogenic Activity in the Indus River Sedimentary Environment in Pakistan: A Critical Review. J. Mar. Sci. Eng. 2021, 9, 1109. [CrossRef]

16. Shah, S.A.H. Strategy for mineral sector development in Pakistan. Minist. Plan. 2018, 3, 1-24.

17. Wang, K.-P.; Chin, E. Mineral Economics and Basic Industries in Asia; Routledge: London, UK, 2019.

18. Vinti, G.; Vaccari, M. Natural resources. Consumption, pollution, and health risks: Developed versus developing economies. In The Routledge Handbook of Waste, Resources and the Circular Economy; Routledge: London, UK, 2020; pp. 11-19.

19. Rodionova, I. Global industrial development trends: Dynamics and regional aspects. Вестник Казну. СерияГеографическая 2021, 60, 17-26. [CrossRef]

20. Igaliyeva, L.; Niyazbekova, S.; Serikova, M.; Kenzhegaliyeva, Z.; Mussirov, G.; Zueva, A.; Tyurina, Y.; Maisigova, L. Towards Environmental Security via Energy Efficiency: A Case Study. Entrepreneurship 2020, 7, 3488-3499. [CrossRef]

21. Shahani, N.M.; Sajid, M.J.; Zheng, X.; Brohi, M.A.; Jiskani, I.M.; Ul Hassan, F.; Qureshi, A.R. Statistical analysis of fatalities in underground coal mines in Pakistan. Energy Sources Part A Recovery Util. Environ. Eff. 2020, 6, 1-16. [CrossRef]

22. Shahani, N.M.; Sajid, M.J.; Jiskani, I.M.; Ullah, B.; Qureshi, A.R. Comparative analysis of coal Miner's fatalities by fuzzy logic. J. Min. Environ. 2021, 12,77-87.

23. Ishtiaq, M.; Jehan, N.; Khan, S.A.; Muhammad, S.; Saddique, U.; Iftikhar, B. Potential harmful elements in coal dust and human health risk assessment near the mining areas in Cherat, Pakistan. Environ. Sci. Pollut. Res. 2018, 25, 14666-14673. [CrossRef] [PubMed]

24. Gomes, C.S.; Silva, E.A. Health Benefits and Risks of Minerals: Bioavailability, Bio-Essentiality, Toxicity, and Pathologies. In Minerals Latu Sensu and Human Health; Springer: Berlin/Heidelberg, Germany, 2021; pp. 81-179. 
25. Rehman Ur, I.; Ishaq, M.; Ali, L.; Khan, S.; Ahmad, I.; Din, I.U.; Ullah, H. Enrichment, spatial distribution of potential ecological and human health risk assessment via toxic metals in soil and surface water ingestion in the vicinity of Sewakht mines, district Chitral, Northern Pakistan. Ecotoxicol. Environ. Saf. 2018, 154, 127-136. [CrossRef]

26. Lassila, M. The Arctic mineral resource rush and the ontological struggle for the Viiankiaapa peatland in Sodankylä, Finland. Globalizations 2021, 18, 635-649. [CrossRef]

27. Ali, D.; Rehman, A.U. Adoption of autonomous mining system in Pakistan-Policy, skillset, awareness and preparedness of stakeholders. Resour. Policy 2020, 68, 101796. [CrossRef]

28. Shengo, L. Review of Practices in the Managements of Mineral Wastes: The Case of Waste Rocks and Mine Tailings. Water Air Soil Pollut. 2021, 232, 1-31. [CrossRef]

29. Rudakov, M.L. Assessment of environmental and occupational safety in mining industry during underground coal mining. $J$. Environ. Manag. Tour. (JEMT) 2020, 11, 579-588. [CrossRef]

30. Graczyk, H.; François, M.; Krief, P.; Guseva Canu, I. The role of the Swiss list of occupational diseases in the protection of workers' health. Swiss Med. Wkly. 2021, 151, w20538. [CrossRef]

31. Bahn, S. Workplace hazard identification and management: The case of an underground mining operation. Saf. Sci. 2013, 57, 129-137. [CrossRef]

32. Schulte, P.A.; Chun, H. Climate change and occupational safety and health: Establishing a preliminary framework. J. Occup. Environ. Hyg. 2009, 6, 542-554. [CrossRef]

33. Baloch, M.A.; Qureshi, A.A.; Waheed, A.; Ali, M.; Ali, N.; Tufail, M.; Batool, S.; Akram, M.; Iftikhar, P.; Qayyum, H. A study on natural radioactivity in Khewra Salt Mines, Pakistan. J. Radiat. Res. 2012, 53, 411-421. [CrossRef] [PubMed]

34. Khalid, B. Effect of temperature and humidity on salt mine environment. Pak. J. Meteorol. 2010, 7, 71-81.

35. Sherin, S.; Rehman, Z.U.; Husain, S.; Muhammad, N.; Bilal, T. Assessment and Quantification of Risks Associated with Small Scale Mining, Khyber Pakhtunkhwa, Pakistan. Int. J. Econ. Environ. Geol. 2020, 11, 65-69.

36. Sasmito, A.P.; Birgersson, E.; Ly, H.C.; Mujumdar, A.S. Some approaches to improve ventilation system in underground coal mines environment-A computational fluid dynamic study. Tunn. Undergr. Space Technol. 2013, 34, 82-95. [CrossRef]

37. Raza, W.; Saeed, S.; Saulat, H.; Gul, H.; Sarfraz, M.; Sonne, C.; Sohn, Z.-H.; Brown, R.J.; Kim, K.-H. A review on the deteriorating situation of smog and its preventive measures in Pakistan. J. Clean. Prod. 2020, 279, 123676. [CrossRef]

38. Saleem, A. A Rapid Assessment of Bonded Labour in Pakistan's Mining Sector. Int. Labour Off. Geneva 2004, $20,1-33$.

39. Shahani, N.; Sajid, M.; Zheng, X.; Jiskani, I.; Brohi, M.; Ali, M.; Ullah, B.; Qureshi, A. Mining of Mineral Deposits. J. Homepage 2019, 13, 121-128. Available online: http://mining.in.ua/articles/volume13_4/14.pdf (accessed on 1 October 2021).

40. Jiskani, I.M.; Cai, Q.; Zhou, W.; Chang, Z.; Chalgri, S.R.; Manda, E.; Lu, X. Distinctive model of mine safety for sustainable mining in Pakistan. Min. Metall. Explor. 2020, 37, 1023-1037. [CrossRef]

41. Jiskani, I.M.; Chalgri, S.R.; Memon, S.; Shahani, N.M.; Qureshi, A.R.; Jarwar, Z.A. Prospective study on safety climate of surface mining in Pakistan. J. Sustain. Min. 2020, 19, 2. [CrossRef]

42. Batool, K.A. Occupational Health Hazards in Mining in Pakistan: An Overview. Eur. Acad. Res. 2015, 3, 5306-5319.

43. Ishtiaq, M.; Nawaz, R.; Khan, K.U.; Khan, H.U.; Zakir, S.; Sarwar, G.; Jehan, N. Prevalance of pneumoconiosis among coal miners of Cherat, district Nowshera-Pakistan. J. Postgrad. Med Inst. 2014, 28, 139-144.

44. Kunda, R.; Frantz, J.; Karachi, F. Prevalence and ergonomic risk factors of work-related musculoskeletal injuries amongst underground mine workers in Zambia. J. Occup. Health 2013, 55, 211-217. [CrossRef]

45. Amponsah-Tawiah, K.; Leka, S.; Jain, A.; Hollis, D.; Cox, T. The impact of physical and psychosocial risks on employee well-being and quality of life: The case of the mining industry in Ghana. Saf. Sci. 2014, 65, 28-35. [CrossRef]

46. Mościcka-Teske, A.; Sadłowska-Wrzesińska, J.; Najder, A.; Butlewski, M. The relationship between psychosocial risks and occupational functioning among miners. Int. J. Occup. Med. Environ. Health 2019, 32, 87-98. [CrossRef]

47. Pollard, J.; Heberger, J.; Dempsey, P.G. Maintenance and repair injuries in US mining. J. Qual. Maint. Eng. 2014, $20,20-31$. [CrossRef]

48. Karliński, J.; Ptak, M.; Działak, P.; Rusiński, E. The approach to mining safety improvement: Accident analysis of an underground machine operator. Arch. Civ. Mech. Eng. 2016, 16, 503-512. [CrossRef]

49. Dhillon, B.S. Mining equipment safety: A review, analysis methods and improvement strategies. Int. J. Min. Reclam. Environ. 2009, 23, 168-179. [CrossRef]

50. Soni, A.; Nema, P. Limestone Mining, Industry, and Society. In Limestone Mining in India; Springer: Berlin/Heidelberg, Germany, 2021; pp. 41-67.

51. Remen, T.; Acouetey, D.; Paris, C.; Hannhart, B.; Poussel, M.; Chenuel, B.; Barbaud, A.; Zmirou-Navier, D. Early incidence of occupational asthma is not accelerated by atopy in the bakery/pastry and hairdressing sectors. Int. J. Tuberc. Lung Dis. 2013, 17, 973-981. [CrossRef]

52. Hermanus, M. Occupational health and safety in mining-status, new developments, and concerns. J. S. Afr. Inst. Min. Metall. 2007, 107, 531-538.

53. Lawson, S.M.; Masterson, E.A.; Azman, A.S. Prevalence of hearing loss among noise-exposed workers within the Mining and Oil and Gas Extraction sectors, 2006-2015. Am. J. Ind. Med. 2019, 62, 826-837. [CrossRef]

54. Kirchsteiger, C. On the use of probabilistic and deterministic methods in risk analysis. J. Loss Prev. Process. Ind. 1999, 12, 399-419. [CrossRef] 
55. Ni, H.; Chen, A.; Chen, N. Some extensions on risk matrix approach. Saf. Sci. 2010, 48, 1269-1278. [CrossRef]

56. Gul, M.; Guneri, A.F. A fuzzy multi criteria risk assessment based on decision matrix technique: A case study for aluminum industry. J. Loss Prev. Process. Ind. 2016, 40, 89-100. [CrossRef]

57. Ma, Y.; Deilami, K.; Egodawatta, P.; Liu, A.; McGree, J.; Goonetilleke, A. Creating a hierarchy of hazard control for urban stormwater management. Environ. Pollut. 2019, 255, 113217. [CrossRef]

58. Morris, G.A.; Cannady, R. Proper use of the hierarchy of controls. Prof. Saf. 2019, 64, 37-40.

59. Zhou, S.; Yang, P. Risk management in distributed wind energy implementing Analytic Hierarchy Process. Renew. Energy 2020, 150, 616-623. [CrossRef]

60. Marhavilas, P.K.; Filippidis, M.; Koulinas, G.K.; Koulouriotis, D.E. The integration of HAZOP study with risk-matrix and the analytical-hierarchy process for identifying critical control-points and prioritizing risks in industry-A case study. J. Loss Prev. Process. Ind. 2019, 62, 103981. [CrossRef]

61. Manzi, M.; Malehmir, A.; Durrheim, R. The value of seismics in mineral exploration and mine safety. In Proceedings of the 81st EAGE Conference and Exhibition, London, UK, 3-6 June 2019; pp. 1-5.

62. Donoso, G.A.; Malehmir, A.; Brodic, B.; Pacheco, N.; Carvalho, J.; Araujo, V. Innovative seismic imaging of volcanogenic massive sulfide deposits, Neves-Corvo, Portugal-Part 2: Surface array. Geophysics 2021, 86, B181-B191. [CrossRef]

63. Chattopadhyay, S.; Chattopadhyay, D. Coal and other mining operations: Role of sustainability. Foss. Energy 2020, 1, $333-356$.

64. Revuelta, M.B. Mineral Resource Extraction. Miner. Resour. 2018, 1, 311-421.

65. Engström, K.G.; Angrén, J.; Björnstig, U.; Saveman, B.-I. Mass casualty incidents in the underground mining industry: Applying the Haddon matrix on an integrative literature review. Disaster Med. Public Health Prep. 2018, 12, 138-146. [CrossRef]

66. Stemn, E.; Hassall, M.E.; Bofinger, C. Systemic constraints to effective learning from incidents in the Ghanaian mining industry: A correspondence analysis and AcciMap approach. Saf. Sci. 2020, 123, 104565. [CrossRef]

67. Onifade, M. Countermeasures against coal spontaneous combustion: A review. Int. J. Coal Prep. Util. 2021, 2, 1-23. [CrossRef]

68. Ammad, S.; Alaloul, W.S.; Saad, S.; Qureshi, A.H. Personal protective equipment (PPE) usage in construction projects: A scientometric approach. J. Build. Eng. 2020, 35, 102086. [CrossRef]

69. Tamers, S.L.; Streit, J.; Pana-Cryan, R.; Ray, T.; Syron, L.; Flynn, M.A.; Castillo, D.; Roth, G.; Geraci, C.; Guerin, R. Envisioning the future of work to safeguard the safety, health, and well-being of the workforce: A perspective from the CDC's National Institute for Occupational Safety and Health. Am. J. Ind. Med. 2020, 63, 1065-1084. [CrossRef]

70. Zhang, H.; Han, W.; Xu, Y.; Wang, Z. Analysis on the Development Status of Coal Mine Dust Disaster Prevention Technology in China. J. Healthc. Eng. 2021, 2021, 5574579. [CrossRef]

71. Fu, G.; Xie, X.; Jia, Q.; Tong, W.; Ge, Y. Accidents analysis and prevention of coal and gas outburst: Understanding human errors in accidents. Process. Saf. Environ. Prot. 2020, 134, 1-23. [CrossRef]

72. Liu, T.; Lin, B.; Xiao, W.; Liu, T.; Yang, W.; Wang, Z.; Zhang, R. A safe mining approach for deep outburst coal seam groups with hard-thick sandstone roof: Stepwise risk control based on gas diversion and extraction. Energy Sci. Eng. 2020, 8, 2946-2965. [CrossRef]

73. Agboola, O.; Babatunde, D.E.; Fayomi, O.S.I.; Sadiku, E.R.; Popoola, P.; Moropeng, L.; Yahaya, A.; Mamudu, O.A. A review on the impact of mining operation: Monitoring, assessment and management. Results Eng. 2020, 8, 100181. [CrossRef]

74. Sanjana, P.; Prathilothamai, M. Drone design for first aid kit delivery in emergency situation. In Proceedings of the 2020 6th International Conference on Advanced Computing and Communication Systems (ICACCS), Coimbatore, Tamil Nadu, India, 6-7 March 2020; pp. 215-220.

75. Suryoputro, M.R.; Buana, F.A.; Sari, A.D.; Rahmillah, F.I. Active and Passive Fire Protection System in Academic Building KH. Mas Mansur, Islamic University of Indonesia. In MATEC Web of Conferences; p. 01094. Available online: https://www.matecconferences.org/articles/matecconf/abs/2018/13/matecconf_icet4sd2018_01094/matecconf_icet4sd2018_01094.html (accessed on 1 October 2021).

76. Ilo, P.I.; Izuagbe, R.; Mole, A.J.; Ekwueme, L. Measuring disaster preparedness and response practices in university libraries in Nigeria: The role of disaster equipment. Int. J. Disaster Risk Reduct. 2018, 31, 85-91. [CrossRef]

77. Papadopoulou, M.; Da Col, F.; Mi, B.; Bäckström, E.; Marsden, P.; Brodic, B.; Malehmir, A.; Socco, L.V. Surface-wave analysis for static corrections in mineral exploration: A case study from central Sweden. Geophys. Prospect. 2020, 68, 214-231. [CrossRef]

78. Park, S.; Choi, Y. Applications of unmanned aerial vehicles in mining from exploration to reclamation: A review. Minerals 2020, 10, 663. [CrossRef]

79. Song, H.; Jeong, S.; Lee, E.; Alsabbagh, N.; Lee, J.; You, S.; Kwak, C.; Kim, S.; Han, W. Types of Hearing Protection Devices and Application. Korean J. Otorhinolaryngol.-Head Neck Surg. 2019, 62, 1-14. [CrossRef]

80. Otoo, J.K. The Determinants of Hearing Protection Device Use among Noise-Exposed Workers of Chirano Gold Mines; University of Ghana: Accra, Ghana, 2019.

81. Ilbahar, E.; Karaşan, A.; Cebi, S.; Kahraman, C. A novel approach to risk assessment for occupational health and safety using Pythagorean fuzzy AHP \& fuzzy inference system. Saf. Sci. 2018, 103, 124-136.

82. Bartkowiak, G.; Baszczyński, K.; Bogdan, A.; Brochocka, A.; Dąbrowska, A.; Hrynyk, R.; Irzmańska, E.; Koradecka, D.; Kozłowski, E.; Majchrzycka, K. Use of Personal Protective Equipment. Handb. Hum. Factors Ergon. 2021, 1, 668-684.

83. Bazaluk, O.; Petlovanyi, M.; Zubko, S.; Lozynskyi, V.; Sai, K. Instability Assessment of Hanging Wall Rocks during Underground Mining of Iron Ores. Minerals 2021, 11, 858. [CrossRef] 
84. Moura, R.; Beer, M.; Patelli, E.; Lewis, J.; Knoll, F. Learning from accidents: Interactions between human factors, technology and organisations as a central element to validate risk studies. Saf. Sci. 2017, 99, 196-214. [CrossRef]

85. Matveykin, V.; Nemtinov, V.; Dmitrievsky, B.; Praveen, K. Development and implementation of network based underground mines safety, rescue and aided rescue system. In Journal of Physics: Conference Series; IOP Publishing: Bristol, UK, 2019 ; p. 012017. [CrossRef]

86. Tong, R.; Yang, Y.; Ma, X.; Zhang, Y.; Li, S.; Yang, H. Risk assessment of Miners' unsafe behaviors: A case study of gas explosion accidents in coal mine, China. Int. J. Environ. Res. Public Health 2019, 16, 1765. [CrossRef] [PubMed]

87. Mukai, N.; Fujita, K.; AL-Kasasbeh, A.; Karrani, S.M.; Al-Marzouqi, A. A New Approach to the Feasibility Design in Development Fields. In Proceedings of the SPE/IADC Middle East Drilling Technology Conference and Exhibition, Abu Dhabi, United Arab Emirats, 26-28 January 2016; pp. 512-520.

88. Sherrigton, C. Slips Trips and Falls in Northern Ontario Underground Hard-Rock Mines; Laurentian University of Sudbury: Sudbury, ON, Canada, 2020.

89. Jain, P.; Pasman, H.J.; Waldram, S.; Pistikopoulos, E.; Mannan, M.S. Process Resilience Analysis Framework (PRAF): A systems approach for improved risk and safety management. J. Loss Prev. Process. Ind. 2018, 53, 61-73. [CrossRef] 